\title{
T29 - Análisis de la red intermodal de transporte de Centroamérica
}

\author{
Kristel Suárez \\ Universidad Marítima Internacional de Panamá, Panamá.
}

*Autor al que se dirige la correspondencia: jcasas@umip.ac.pa

\section{Resumen}

$\mathrm{C}$ Yentroamérica es dependiente del transporte terrestre para su intercambio comercial puesto que hay poca integración con los otros medios de transporte y son reducidas las opciones para el transporte de carga entre los países de la región. Es por esta razón que se llevan a cabo estudios para promover otras opciones como el Transporte Marítimo de Corta Distancia (TMCD). Pero expertos en la región advierten que más allá de presentar una opción al transporte por carretera, es necesario articular las infraestructuras y servicios de transporte en una red intermodal de transporte. Bajo este concepto, el presente estudio compara el desempeño del sistema intermodal de transporte de Centroamérica incorporando rutas de TMCD en relación con el actual desempeño de la red de carreteras. La región bajo estudio cuenta con escasas líneas ferroviarias y las existentes no se interconectan a la red por lo que se descartan en el análisis. Se comprueba que los países de mayor intercambio comercial intrarregional, son también los que cuentan con los mayores niveles de conectividad de la región. Ciudades como Managua y San Salvador cuentan con potencial tanto para el intercambio comercial como para el desarrollo de actividades logísticas. Se destaca la importancia de establecer conexione marítimas para aumentar el nivel de conectividad de la mayoría de las ciudades de Centroamérica.

Palabras claves: Transporte marítimo, intercambio comercial

\begin{abstract}
$\mathrm{C}$ Yentral America is dependent on road transport for trade since there is little integration with other modes of transport and are reduced options for cargo transportation between the countries of the region. For that reason, studies are carried out to promote other modes such as Short Sea Shipping (SSS). But regional experts point out that it is necessary to coordinate infrastructure and transport services in an intermodal transport network, beyond than presenting an option to road transport. Under this concept, the present study compares the performance of the intermodal transport system incorporating Central American SSS routes in relation to the current performance of the road network. The region under study has few existing railway lines and they are not interconnected to the network so discarded in the analysis. It is found that countries with higher intraregional trade are also those with the highest levels of connectivity in the region. Cities as Managua and San Salvador have potential for both trade and the logistics development. It is highlighted the importance of maritime connection in order to increase the level of connectivity of most cities in Central America.
\end{abstract}

Keywords: Maritime transportation, commercial exchange 